\title{
出生前診断された中枢神経系異常例の現状と長期追跡調査
}

\author{
埜中 正博1)，山崎 麻美 ${ }^{2}$, 淺井 昭雄 ${ }^{1)}$
}

1）関西医科大学脳神経外科，2）高槻病院小児脳神経外科

\section{Long Term Outcome of Prenatally Diagnosed Neurosurgical Diseases}

\author{
Masahiro Nonaka, M.D. ${ }^{1)}$, Mami Yamasaki, M.D. ${ }^{2)}$, and Akio Asai, M.D. ${ }^{1)}$ \\ 1) Department of Neurosurgery, Kansai Medical University, 2) Department of Pediatric Neurosurgery, Takatsuki General \\ Hospital
}

Recent advances in imaging and molecular diagnostic technology have increased the rates of the prenatal diagnosis of neurosurgical central nervous system abnormalities. However, the prognosis of the patients who were diagnosed prenatally are not well known. We report our experience of 62 patients who were available for follow-up study, and 18 aborted cases. The mean diagnosis time of born cases was 29.8 weeks (18 weeks-39 weeks), and aborted cases was 18.2 weeks (13 weeks-24 weeks). The mean age of born cases was 7.3 years (0-25 years), and the born cases included 23 myelomeningocele, 9 isolated ventriculomegaly, and 8 fetal intraventricular hemorrhage. Among aborted cases, there was 7 myelomeningocele, and 6 genetic abnormalities such as hereditary hydrocephalus. 11 cases of the born cases died, and the surviving cases differed in prognosis depending on the disease. We assessed DQ/IQ of the surviving patients older than 2 years old $(n=54) .26$ survivnig cases were normal $(D Q, I Q>80), 8$ cases were with mild disability (60-79), 3 cases with moderate disability (40-59), and 3 cases with severe disability $(<39)$. Of prenatally diagnosed cases, the prognosis varied significantly depending on the disease, however nearly half of cases that were able to follow up had normal development. Improved accuracy of the diagnosis was thought to be necessary for prenatal diagnosis.

(Received May 17, 2017 ; accepted June 14, 2017)

Key words : fetal diagnosis, hydrocephalus, myelomeningocele

Jpn J Neurosurg（Tokyo） $26: 581-586,2017$

\section{はじめに}

出生前診断は主に産科医や小児科医が関わっている が，胎児の超音波画像検査では脳室の大きさなど頭部の 病変が発見されることも比較的多いことから，脳神経外 科医の意見が求められる機会がある。特に水頭症，脊䯣 髄膜瘤，脳腫瘍については脳神経外科医としての専門的 な知識が求められる。 その際治療により良好な経過をたどる可能性がある症
例を，出生前に誤解に基づき予後不良と説明したため出 生後に両親がこどもの治療を拒否するなど悲劇的な結果 を招いてしまう危険性があることを認識する必要があ る. 出生前診断の現状と限界を一般的な脳神経外科医に も理解してもらい，日常診療に役立つように自験例を交 えて解説する。 
Table 1 Numbers of prenatally diagnosed cases by disease

\begin{tabular}{|c|c|c|c|c|c|c|c|c|c|c|}
\hline & \multirow[b]{2}{*}{$\begin{array}{c}\text { Myelo- }^{-} \\
\text {meningocele }\end{array}$} & \multicolumn{4}{|c|}{ Hydrocephalus } & \multirow[b]{2}{*}{$\begin{array}{l}\text { Brain } \\
\text { tumor }\end{array}$} & \multirow[b]{2}{*}{$\begin{array}{c}\text { Arachnoid } \\
\text { cyst }\end{array}$} & \multirow[b]{2}{*}{ Encephalocele } & \multirow[b]{2}{*}{ Others } & \multirow[b]{2}{*}{ Total } \\
\hline & & $\begin{array}{l}\text { Post-intra- } \\
\text { ventricular } \\
\text { hemorrhage }\end{array}$ & $\begin{array}{c}\text { Genetic or } \\
\text { karyographic } \\
\text { abnormality }\end{array}$ & $\begin{array}{c}\text { Hydranen- } \\
\text { cephaly }\end{array}$ & \begin{tabular}{|l} 
Isolated \\
ventricu- \\
lomegaly
\end{tabular} & & & & & \\
\hline $\begin{array}{c}\text { Born alive } \\
\text { Aborted } \\
\text { Total }\end{array}$ & $\begin{array}{c}23 \\
7 \\
30\end{array}$ & $\begin{array}{c}8 \\
2 \\
10\end{array}$ & $\begin{array}{l}2 \\
6 \\
8\end{array}$ & $\begin{array}{l}3 \\
0 \\
3\end{array}$ & $\begin{array}{c}9 \\
1 \\
10\end{array}$ & $\begin{array}{l}4 \\
0 \\
4\end{array}$ & $\begin{array}{l}5 \\
0 \\
5\end{array}$ & $\begin{array}{l}3 \\
0 \\
3\end{array}$ & $\begin{array}{l}5 \\
2 \\
7\end{array}$ & $\begin{array}{l}62 \\
18 \\
80\end{array}$ \\
\hline
\end{tabular}

Table 2 Numbers of prenatally diagnosed cases and timing of initial diagnosis

\begin{tabular}{c|c|c|c|c}
\hline $\begin{array}{c}\text { Gestational weeks } \\
\text { at diagnosis }\end{array}$ & $22 \mathrm{w}>$ & $\begin{array}{c}22 \mathrm{w} \leqq \\
31 \mathrm{w}>\end{array}$ & $31 \mathrm{w} \leqq$ & Total \\
\hline Born alive & 9 & 23 & 30 & 62 \\
Aborted & 17 & 1 & 0 & 18 \\
Total & 26 & 24 & 30 & 80 \\
\hline
\end{tabular}

Table 4 Developmental prognosis and timing of initial diagnosis

\begin{tabular}{|c|c|c|c|c|}
\hline $\begin{array}{l}\text { Gestational weeks } \\
\text { at diagnosis }\end{array}$ & $22 \mathrm{w}>$ & $\begin{array}{l}22 \mathrm{w} \leqq \\
31 \mathrm{w}>\end{array}$ & $31 \mathrm{w} \leqq$ & Total \\
\hline DQ/IQ 50> & 1 & 2 & 2 & 5 \\
\hline $\mathrm{DQ} / \mathrm{IQ} 50 \leqq 70>$ & 0 & 6 & 5 & 11 \\
\hline $\mathrm{DQ} / \mathrm{IQ} 70 \leqq$ & 3 & 9 & 20 & 32 \\
\hline Not examined & 2 & 1 & 0 & 3 \\
\hline Average DQ/IQ & 73.5 & 68.5 & 81.7 & 74.6 \\
\hline
\end{tabular}

\section{対象・方法}

筆頭著者が関わつた出生前診断された症例のうち，現 在まで追跡が可能であった例，経過中に死亡した例，お よび妊娠中絶に至った例合計 80 例を対象とした。出生 前診断された時期の平均は 27.5 週で, 追跡可能例の平均 診断時期は 29.8 週（18３9 週，22 週未満は 9 例)，妊娠 中絶例は 18.2 週 (13〜24 週)であった。追跡可能例の平 均年齢は 7.3 歳（0～25 歳）であった。生存している 62 例については, 2 歳以上 6 歳以下の症例に対しては指数 （developmental quotient：DQ, 新版 $\mathrm{K}$ 式発達検査）を, 7 歳以上の症例に対しては $\mathrm{IQ}$ (Wechsler Intelligence Scale for Children：WISC-III・IV) を計測した。対象となった 症例の出生前診断は胎児超音波検査にて異常が疑われた 胎児に対し, MRI 検査, 羊水検査, 絨毛検査による遺伝 子検査を必要に応じて追加して実施した。出生前診断さ れた症例の疾患の内訳は多い順に，水頭症，脊髄髄膜瘤， くも膜囊胞，脳腫瘍，脳瘤，その他であった（Table 1).
Table 3 Prognosis of life and timing of initial diagnosis

\begin{tabular}{c|c|c|c|c}
\hline $\begin{array}{c}\text { Gestational weeks } \\
\text { at diagnosis }\end{array}$ & $22 \mathrm{w}>$ & $\begin{array}{c}22 \mathrm{w} \leqq \\
31 \mathrm{w}>\end{array}$ & $31 \mathrm{w} \leqq$ & Total \\
\hline Died before 1 y. o. & 2 & 4 & 1 & 7 \\
Died after 1 y. o. & 1 & 1 & 2 & 4 \\
Alive & 6 & 18 & 27 & 51 \\
\hline
\end{tabular}

水頭症については，その原因別に，胎内で脳室内出血を 引き起こしたことに起因する水頭症 (出血後水頭症), 遺 伝子変異や染色体異常に起因する水頭症（遺伝性水頭 症)，大脳半球が形成されず，欠損部に髄液が貯留してい る水無脳症 (水無脳症), その他の原因による水頭症 (単 純性水頭症）と分類した（Table 1).

\section{結 果}

出生前診断された時期 : 母体保護法により定められてい る妊娠 21 週 6 日まで（妊娠 22 週未満）に診断された症 例は 26 例で，うち 17 例では妊娠の中絶が選択された。 22〜30 週にかけては 24 例で，この時期に中絶した 1 例 は外国人で母国にて妊娠中絶を施行された。 31 週以降に 診断された症例は 30 例であった（Table 2)，死産となっ た症例はなかった。

出生した症例の予後：1歳未満で死亡した症例が 7 例で, 1 歳以降に死亡した症例は 4 例であった。 1 歳未満で死亡 した症例のうち，2 例は合併する心奇形による心不全の ため死亡した。死亡した症例と，診断された時期の明ら かな関連性は認めら机なかった (Table 3)。 また生存例の $\mathrm{DQ} / \mathrm{IQ}$ については，重度の発達障害に該当する 50 未満 の例は 5 例，軽度の発達障害に相当する 50 以上 70 未満 の症例が 11 例， 70 以上で正常範囲内にあると考えられ た症例は 32 例であった (Table 4)。平均 $\mathrm{DQ} / \mathrm{IQ}$ について は, 出生前診断された時期との明らかな相関関係を認め なかった（Table 4)。疾患別にみると, 脊髄髄膜瘤は 1 歳 以下の死亡例は 0 例， 1 歳以上の死亡例は 2 例で，いず 
Table 5 Prognosis of prenatally diagnosed myelomeningocele and timing of initial diagnosis

\begin{tabular}{|c|c|c|c|c|}
\hline $\begin{array}{l}\text { Gestational weeks } \\
\text { at diagnosis }\end{array}$ & $22 \mathrm{w}>$ & $\begin{array}{l}22 \mathrm{w} \leqq \\
31 \mathrm{w}>\end{array}$ & $31 \mathrm{w} \leqq$ & Total \\
\hline Died before 1 y. $о$. & 0 & 0 & 0 & 0 \\
\hline Died after 1 у. о. & 0 & 0 & 2 & 2 \\
\hline DQ/IQ 50> & 0 & 2 & 0 & 2 \\
\hline $\mathrm{DQ} / \mathrm{IQ} 50 \leqq 70>$ & 0 & 2 & 2 & 4 \\
\hline $\mathrm{DQ} / \mathrm{IQ} 70 \leqq$ & 2 & 5 & 7 & 14 \\
\hline Not examined & 1 & 0 & 0 & 1 \\
\hline
\end{tabular}

れもキアリ 2 型奇形による呼吸不全が背景にある感染症 が原因となっていた。生存例の $\mathrm{DQ} / \mathrm{IQ}$ については, 50 未満 2 例, 50 以上 70 未満は 4 例で, 70 以上の例は 14 例 と 3 分の 2 近くをを占めていた. 診断の契機については, ほとんどの症例（22 例）が脳室拡大の精査により診断さ れていた（Table 5).

水頭症については 1 歳未満の死亡例は 5 例, 1 歳以上 の死亡例は 2 例であった. 生存例の $\mathrm{DQ} / \mathrm{IQ}$ については, 50 未満 1 例， 50 以上 70 未満は 5 例で, 70 以上の例は 8 例と,かなりのばらつきを認めていた（Table 6)。水頭症 を原因別にみていくと, 胎内での脳室内出血による水頭 症は全例生存しており $\mathrm{DQ} / \mathrm{IQ}$ は 50 以上 70 未満は 2 例 で, 70 以上の例は 5 例と比較的予後は良好であった。一 方既知の遺伝子異常や，原因や合併奇形を有さない単純 性水頭症（isolated ventriculomegaly）については，1歳未 満で死亡した例が 3 例， $\mathrm{DQ} / \mathrm{IQ}$ が 50 未満であった症例 が 1 例あった一方, DQ/IQ が 50 以上 70 未満は 2 例で, 70 以上の例は 3 例と予後についてはかなりのばらつきを 認めていた (Table 7). 水無脳症, 遺伝子異常, もしくは 染色体異常を合併する水頭症については，予後はいずれ も不良であった。

くも膜囊胞については，全例が生存しており，DQ/IQ が 50 以上 70 未満は 1 例で, 70 以上の例は 4 例とかなり 予後がよい傾向を認めていた。

脳腫瘍を含むその他の疾患については，原疾患により 予後が左右される傾向がみられたものの, 症例数が少な く予後についてもばらつきが大きかった。

出生前診断と出生後の診断が異なっていた例は 4 例 で，いずれも脊髄髄膜瘤に関連した症例であった。䯣膜 瘤が検出されず，合併奇形のない水頭症と診断された症 例は 3 例で，これらはいずれも超音波検査のみにて診断 された症例であった。残りの 1 例は 20 週時に脊髄髄膜瘤 と診断された症例で，出生後に皮膚欠損のない潜在性二 分脊椎である脊髄脂肪髄膜瘤と診断されている。
Table 6 Prognosis of prenatally diagnosed hydrocephalus and timing of initial diagnosis

\begin{tabular}{|c|c|c|c|c|}
\hline $\begin{array}{c}\text { Gestational weeks } \\
\text { at diagnosis }\end{array}$ & $22 \mathrm{w}>$ & $\begin{array}{l}22 \mathrm{w} \leqq \\
31 \mathrm{w}>\end{array}$ & $31 \mathrm{w} \leqq$ & Total \\
\hline Died before 1 у. o. & 3 & 2 & 0 & 5 \\
\hline Died after 1 у. o. & 0 & 2 & 0 & 2 \\
\hline DQ/IQ 50> & 1 & 0 & 0 & 1 \\
\hline $\mathrm{DQ} / \mathrm{IQ} 50 \leqq 70>$ & 0 & 3 & 2 & 5 \\
\hline $\mathrm{DQ} / \mathrm{IQ} 70 \leqq$ & 1 & 1 & 6 & 8 \\
\hline
\end{tabular}

Table 7 Prognosis of prenatally diagnosed isolated ventriculomegaly and timing of initial diagnosis

\begin{tabular}{|c|c|c|c|c|}
\hline $\begin{array}{l}\text { Gestational weeks } \\
\text { at diagnosis }\end{array}$ & $22 \mathrm{w}>$ & $\begin{array}{l}22 \mathrm{w} \leqq \\
31 \mathrm{w}>\end{array}$ & $31 \mathrm{w} \leqq$ & Total \\
\hline Died before 1 y. o. & 2 & 1 & 0 & 3 \\
\hline Died after 1 y. o. & 0 & 0 & 0 & 0 \\
\hline DQ/IQ 50> & 1 & 0 & 0 & 1 \\
\hline $\mathrm{DQ} / \mathrm{IQ} 50 \leqq 70>$ & 0 & 1 & 1 & 2 \\
\hline $\mathrm{DQ} / \mathrm{IQ} 70 \leqq$ & 1 & 0 & 2 & 3 \\
\hline
\end{tabular}

\section{考 察}

生まれる前の胎児がどのような状態にあるのかについ ては長らくブラックボックスの状態にあり，胎児の状態 を知る手掛かりは母体の腹囲や胎児心音など，間接的な 診察による方法に限られていた。1950年代以降は羊水中 の細胞の染色体を調べることで，性別 ${ }^{10)}$ や染色体異常 ${ }^{14}$ を出生前に診断することが可能となった．出生前診断に 大きな進歩をもたらしたのは超音波診断装置の開発であ る。スコットランドの産科医師 Donald $ら^{8)}$ により開発さ れた腹部用の超音波装置はその後胎児の診断に用いられ るようになる，その後，超音波診断装置による胎児の頭 部計測の手法が確立していった ${ }^{4)}$ ，中枢神経系の胎児診 断は 1970 年代より徐々に普及するようになってきた。 これは超音波画像診断装置の進歩によるもので, 1972 年 には水頭症の胎児診断が報告され ${ }^{13)}, 1975$ 年になると春 髄髄膜瘤の胎児診断が報告されるようになっている また生化学的な診断の進歩もこの時期にあり，1972 年に は羊水中 ${ }^{2)}, 1974$ 年には母体血清中 ${ }^{3)} の$ alpha-fetoprotein が無脳症と奉髄髄膜瘤の診断に有用であることが報告さ れている，さらに近年になると胎児診断にMRIを用いる ようになり，超音波診断の弱点である術者間の診断技術 の差がなくなり, 診断が困難である水頭症や囊胞性病変 以外の病変の診断精度が向上した。

また 1980 年代になると胎児診断された水頭症を胎児 
期に治療した報告がなされた ${ }^{7)} .1984$ 年には Chervenak $ら^{6)}$ により胎児診断された脳室拡大例の予後調査では, 妊娠中絶に至った症例が 13 例 (26\%), 周産期から新生 児期の死亡例が 21 例（44\%）で，生存していた症例は 14 例（28\%）となっていた。生存している症例でも精神 運動発達に問題がなかった症例は 14 例中 2 例に留まっ ていた。 1988 年の Hudgins ら ${ }^{9)}$ の報告では, 脳室拡大例 47 例中中絶例 15 例（31\%）を除く 32 症例で, 正常発達 していた症例は 13 例で, 出生例の $40 \%$ 近くに上ってい た。今回の報告は当時の報告からおよそ 30 年近く経過 しており, 周産期の管理や水頭症治療の水準が向上した 影響か，出生例 62 例のうち，32 例 $(52 \%)$ で正常の発 育を遂げていた。うち脳室の拡大のみを認めていた症例

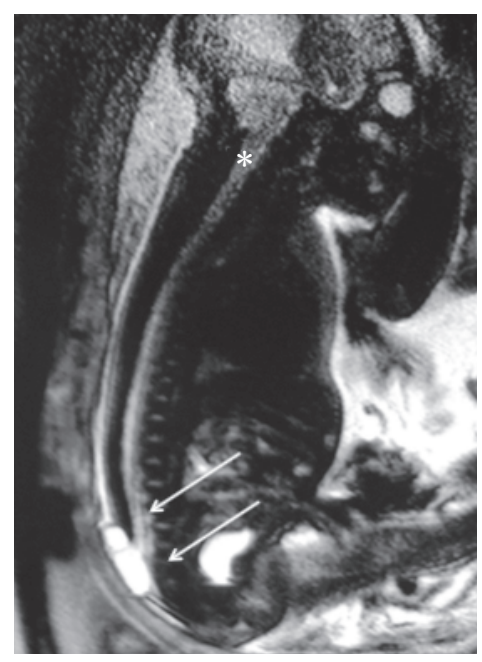

Fig. 1 Sagittal heavily T2-weighted MR image of prenatally diagnosed myelomeningocele. Chiari malformation (asterisk) and meninigocele (arrows) are visualized.
については 21 例中 8 例 $(38 \%)$ で正常であつた。また春 髄髄膜瘤の症例についても，そのほとんど $(22 / 23$ 例) は 脳室拡大による診断例であるが, 22 例中 13 例 $(60 \%)$ の 発達は正常であった。脳室拡大例の予後については，近 年はおよそ半数が正常発達を遂げる可能性があると考え られる。

水頭症などの異常が妊娠のどの時期に発見されるかに よって予後に影響するのかどうかについても，近年変

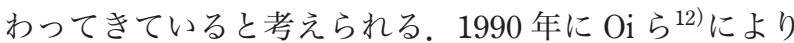
脳室拡大がいつ診断されたのかが予後に影響すると報告 された。より早期に異常が診断されれば予後が悪くなる という。しかし 2012 年の Yamasaki らの報告 ${ }^{15)}$ ，および 今回の検討では，診断時期と予後の明らかな相関を認め ていなかった。その原因としては，診断に用いている超 音波検査機器や, MRI 撮影法が 20 年以上前より大きく 進歩し，より微細な病変も検出することが可能となって きているためではないかと推測される（Fig. 1，2）.

出生前診断される疾患のうち，予後が比較的よいもの はくも膜囊胞，春髄髄膜瘤，胎児脳室内出血後水頭症 ${ }^{15)}$ であり，遺伝性水頭症や水無脳症については悪い傾向が みられた。

診断の正確性については，予後良好の疾患を予後不良 と診断してしまうことが問題となる。 22 週未満であれば その診断結果に基づき両親が中絶を選択する可能性があ るためである，特に問題となるのは脊髄髄膜瘤と脊髄脂 肪髄膜瘤との鑑別である。春髄脂肪䯣膜瘤は春髄髄膜瘤 と異なり潜在性二分脊椎症に該当する疾患で，脊髄髄膜 瘤と比較すると後頭蓋窩病変や水頭症の合併はまれであ $り^{11)}$ ，下肢の運動障害や膀胱直腸障害も軽度である。今 回解析した症例の中でも 20 週時に脊髄髄膜瘤と診断さ れた脊髄脂肪䯣膜瘤の症例については，両親が産むこと
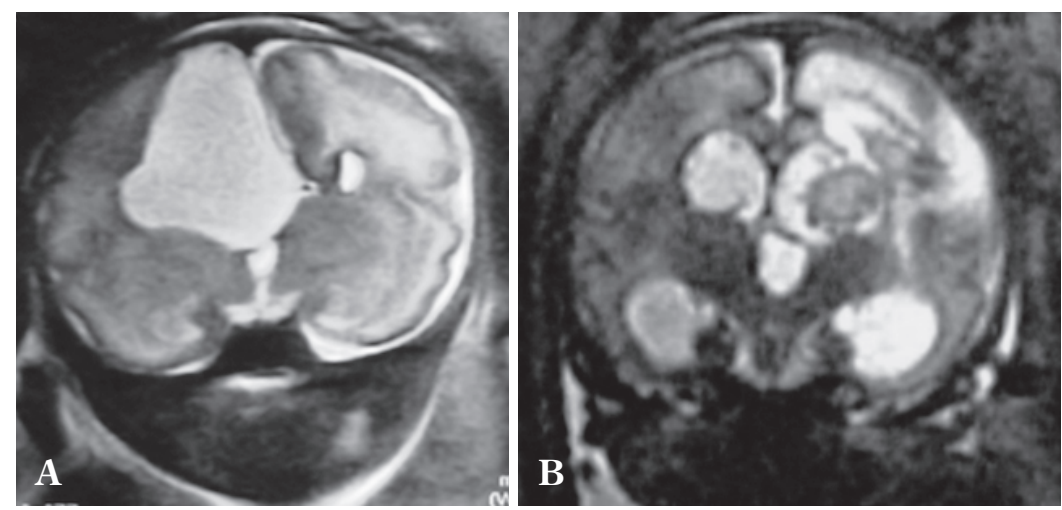

Fig. 2 Coronal heavily T2-weighted MR image of prenatally diagnosed interhemispheric arachnoid cyst (A) and intrauterine intraventricular hemorrhage $(\mathbf{B})$. 
を決意していたため，幸いなことに出生後に当初の診断 が誤りであることが判明した。近年は胎児MRIでの囊胞 壁の厚みや，囊胞壁と皮下組織の連続性を検討すること で脊髄脂肪髄膜瘤を鑑別できる可能性が指摘されてい $ろ^{11)}$.

また出生前診断された胎児に対する胎内治療の試みも 古くから行われている，水頭症に対しては胎内での脳室 穿刺や，脳室羊水シャントが行われたが ${ }^{11)}$ ，この治療の 有効性はのちに否定された。一方脊髄髄膜瘤の胎児治療 については, 出生後に治療した群と比較したランダム化 比較試験において髄液シャントを要する症例の割合，お よびキアリ奇形の割合が減少し, 生後 30 カ月時点での 運動機能, 歩行機能の改善を認めたとし, 早産のリスク があるものの有用性が証明されている ${ }^{11)}$ 。ただし本邦に おいてはいまだ実施されていないのが現状である.

\section{まとめ}

出生前診断された症例は，半数近くが正常に育つが， 原因となっている疾患や合併する疾患により予後が異な るため, より正確な診断を行う必要があると考えられ た。 また出生後と異なる診断が下される危険性があるこ とを十分に認識する必要があると考えられた。

著者のうち埜中と淺井は日本脳神経外科学会への COI 自己 申告の登録を完了しています。

山崎は本年 5 月に逝去したため本論文に関する 2016 年度 COIのみ開示が不可能です。

日本脳神経外科コングレス COI 委員会で論文内容が審査さ れ，特定の企業や営利目的の団体との COI が影響する内容で はないと判断されました。

\section{文 献}

1) Adzick NS, Thom EA, Spong CY, Brock JW 3rd, Burrows PK,
Johnson MP, Howell LJ, Farrell JA, Dabrowiak ME, Sutton LN, Gupta N, Tulipan NB, D’Alton ME, Farmer DL ; MOMS Investigators : A randomized trial of prenatal versus postnatal repair of myelomeningocele. $N$ Engl J Med 364: 9931004, 2011.

2) Brock DJ, Sutcliffe RG : Alpha-fetoprotein in the antenatal diagnosis of anencephaly and spina bifida. Lancet $2: 197$ 199, 1972.

3) Brock DJ, Bolton AE, Scrimgeour JB : Prenatal diagnosis of spina bifida and anencephaly through maternal plasmaalpha-fetoprotein measurement. Lancet 1:767-769, 1974.

4) Campbell S: An improved method of fetal cephalometry by ultrasound. J Obstet Gynaecol Br Commonw 75: 568-576, 1968.

5) Campbell S, Pryse-Davies J, Coltart TM, Sellea MJ, Singer JD : Ultrasound in the diagnosis of spina bifida. Lancet $\mathbf{1}$ : 1065-1068, 1975.

6) Chervenak FA, Duncan C, Ment LR, Hobbins JC, McClure M, Scott D, Berkowitz RL : Outcome of fetal ventriculomegaly. Lancet $\quad 2: 179-181,1984$.

7) Clewell WH, Johnson ML, Meier PR, Newkirk JB, Zide SL, Hendee RW, Bowes WA Jr, Hecht F, O'Keeffe, Henry GP, Shikes RH : A surgical approach to the treatment of fetal hydrocephalus. N Engl J Med 306 : 1320-1325, 1982.

8) Donald I, Macvicar J, Brown TG : Investigation of abdominal masses by pulsed ultrasound. Lancet $\quad \mathbf{1}$ : 1188-1195, 1958.

9) Hudgins RJ, Edwards MS, Goldstein R, Callen PW, Harrison MR, Filly RA, Golbus MS : Natural history of fetal ventriculomegaly. Pediatrics $\quad 82: 692-697,1988$.

10) Makowski EL, Prem KA, Kaiser IH : Detection of sex of fetuses by the incidence of sex chromatin body in nuclei of cells in amniotic fluid. Science $123: 542-543,1956$.

11) Nagaraj UD, Bierbrauser KS, Peiro JL, Kline-Fath BM : Differentiating closed versus open spinal dysraphisms on fetal MRI. AJR Am J Roentgenol 207 : 1316-1323, 2016.

12) Oi S, Matsumoto S, Katayama K, Mochizuki M : Pathophysiology and postnatal outcome of fetal hydrocephalus. Childs Nerv Syst 6: 338-345, 1990.

13) Reed MF : Ultrasound in diagnosing hydrocephalus. $\mathrm{Br} \mathrm{Med}$ J 3: 762, 1972.

14) Steele MW, Breg WR Jr: Chromosome analysis of human amniotic-fluid cells. Lancet $\quad \mathbf{1}: 383-385,1966$.

15) Yamasaki M, Nonaka M, Bamba Y, Teramoto C, Ban C, Pooh RK : Diagnosis, treatment, and long-term outcomes of fetal hydrocephalus. Semin Fetal Neonatal Med 17:330-335, 2012. 
要

旨

出生前診断された中枢神経系異常例の現状と長期追跡調査

埜中 正博 山崎 麻美 淺井 昭雄

出生前診断を行った自験 170 例のうち, 現在追跡調査が可能である 62 例と, 人工妊娠中絶に至っ た 18 例の合計 80 例について報告する. 追跡可能例の平均年齢は 7.3 歳（0２5 歳）で, 疾患内訳は 脊髄髄膜瘤 23 例, 単純性水頭症 9 例, 胎児脳室内出血後水頭症 8 例, その他 22 例であった. 追跡可 能例の予後は, 11 例で経過中に死亡していた. 生存していた例は疾患により予後が異なっていたが, 発達については, 正常（DQ/IQ>70）32 例, 中等度 11 例, 重度 5 例であった. 出生前診断された症 例のうち, 追跡調査可能であった症例の半数近くが正常に近い発達を遂げていた. 一方では死亡例も 少なくなく, 疾患によって予後が大きく異なっていた. 出生前診断にはできるだけ正確な診断が必要 であると考えられた.

脳外誌 $26 ： 581-586,2017$ 